\title{
"Citizenship" Facets in the Egyptian Newspapers
}

From 2011 to 2017

Fatma Elzahraa Elsayed

Associate Professor, Journalism

Department Cairo University

Summary:

This research aims to explore the potential interpretations of citizenship across seven years starts in 2011 and ends in 2017. The exploration focuses on the Egyptian media through three of the most popular online newspapers, "Al-Yom Al-Sabea, "Al- Masry Al- Yom" and "Al- Watan". The research is an attempt to detect the possible development of citizenship concept in its three main facets of rights that include the civic, the social, and the political aspects, besides the two dimensions of duties toward the state and the society. Three hypotheses suggest no correlation between presenting any citizenship facets and the discursive arguments that have been used to underpin articles about citizenship rights and duties. The findings indicate rejection of the three hypotheses with limited exceptions that are connected to the varied circumstances of the analysed year. The main conclusion is that there is an evidence that direct significant correlations exist between citizenship rights and duties debates and using a certain discursive argument as a persuasive framework. 


\section{Introduction:}

Measuring the development of concepts across time is a challenging task. Although the definition of "Concept" is straightforward, the exploration of the concept changing is a complicated issue. (Chi, M.T.H. 2008) The primary attempts to study the conceptual change have been carried out by cognitive psychology research to demystify the resistance strategies against conceptual change and suggest policies to exceed this resistance. (Nersessian, N. J. 1992)

Surprisingly, the "Citizenship" concept which pronounced in Arabic as "Mowatanh" is not exist as a lingual term in any of the traditional Arabic language dictionaries. (Abo Zied \& Ezzat, H.R. 2003) However, the term "Watan", which means homeland, exists and it means the place to which a human belongs whether he was born inside or outside it. Some recent Arabic political encyclopaedias define citizenship as a "state of a citizen involves entitlements and duties toward his nation/country". (Abo Zied \& Ezzat, H.R. p28). The previous facts indicate that "citizenship" is not an original concept in the Arabic literature. Nevertheless, there are several attempts to originate it within the Islamic history and explain its existence as part of the conceptual movement that has been associated with the Western occupation of the Arabic world. (Al-Assassy, A. Z. 2011)

This research focuses on the Egyptian newspapers deliberation of citizenship concept across seven years as an attempt to explore the potential interpretations of this concept during transformational times. As the citizenship concept is relatively new in the Egyptian society and has no clear meaning, at least as a lingual term, it is more vulnerable to be interpreted differently and influenced by the powers that generally control the media. The sixteen arguments which have been extracted from citizenship articles across years represent the dominant claims utilized to portray certain meanings that reflect official concerns or direct definitions of citizenship should be delivered to the readers.

\section{Conceptual movement of citizenship:}

Exploring the development of any concept across time may contain the main factors that influence the national deliberation of this concept through the media and estimates its potential effects and relationships with the political system and social circumstances. A citizen is defined as a member of a political community who enjoys the rights and assumes the duties of membership. (Stanford Encyclopedia of philosophy, 2006) However, the meaning of citizenship in its contemporary version may include living and breathing amalgam of the modes of foundation, identity, place, and obsolescence. (John, J. S. 2008) Democratic societies require citizens who act as moral agents in the public sphere. It is mainly connected to the reinvigoration of citizenship influenced by new technology innovations. From a constitutional point of view, citizenship has three dimensions to be understood, the first is a legal-judicial dimension that refers to citizen membership of a political community, the second considers the political activism of the citizen that includes various kinds of communal participation, the third dimension indicates the shared national emotions that unify all society members and confirm their loyalty and belonging to their nation. (Coleman, S. \& Blumler, J. G. 2009) In 
the rhetorical studies of citizenship, there is a casual and unspecified use of the term "citizen". The major concentration is on the political acts that may expand to encompass the entire deeds of a society member. However, referring to the discourse theory of citizenship, all citizens are associated normatively in one political body. (Rufo, $\mathrm{k}$. \& Atchison, R.J. 2011) Militarization of citizenship is a type of relationship between the state as an authorized entity responsible for protecting and defending the citizens and the so-called boarder vigilant groups who act as "Public servants" and their basic mission is to help in controlling the public space and oppressing oppositional voices. It is argued that militarization of citizenship is a consequence of the denationalization of citizenship when a state is weakened too weak to secure the essential rights and services to its citizens. (Robinson Chavez, R. 2017)

The new concept of citizenship that emerges with the development of digital communication connect it with the borderless state of mind rather than the binary opposites of they/we that may allow exclusion and marginalization. (Ivic, S. 2011) Consequently, a new sense of belonging to a certain religious or political identity may indicate connectedness between dispersal users addresses of social media networks in which new concept of digital citizenship emerges. (Zoonen, L. et al 2010) In 2010, A Facebook group named "We are all Khaled Said" represented the iconic identity of the Egyptian citizen under Mubarak regime. The vast popularity of this virtual group based on the conceived similarity between the victim's brutal way of killing and the same possible fate of any Egyptian citizen. (Lim, M. 2012) Civically, the networking possibilities can play a major role in magnifying the sense of citizenship through its open potentials of communication. Galera, M.et al. (2017) argues that networks allow young people to increase their connectivity and emphasize their civic responsibilities. When $50 \%$ of the youth consider networks as a valuable tool in their lives that enables them to mobilize efforts and achieve an active participation in solidarity issues.

The media is one of the main factors that constructs the conceptual meaning of citizenship in the society through the language. The language of the media can change the categorization of people from an ethnic identity to more inclusive language that includes all citizens regardless any discriminative aspects. (Lane, P. 2009). There is some evidence that the media can act as an agent of promoting the development of citizenship, on the other hand, the citizens should have a conscience of their rights and responsibilities. (Omwoha, J. 2017) Moreover, there is an argue that the extensive exposure to contradicted political viewpoints may increase the public knowledge about the political issues, but suppresses the potential participation in the political activities. (Kim, D. H. and Kwak, N. 2017)

In an article analyzed the corpus of UK policy documents (2001-2011) comparing between the discourse of security and counter-terrorism produced by the UK official authorities as a response to 7/7 attacks and to 2001 riots in the North of England. The words "citizenship", "community", and "cohesion" are re-contextualized in 2011 in a way doesn't support the social solidarity. This finding illustrates the potential laxity of presenting concepts influenced by political and social factors. (Mac Donald, M. et al 2013)

In an interesting analysis of how popular culture-such as Harry Potter-can impact 
the social and political activity of the fan groups, (Hinck, A.2015) suggested a theoretical background to explain the modality resonance between actual political identities stances in certain national and international issues and the digital civic engagement of the fan groups political campaign to "re-pair" the ethical framework with civic ethical modalities.

In the context of practicing digital citizenship, (Hintz, A. et al 2017), argued that Snowden has performed a kind of citizenship that is unknown yet. The digital citizenship rights he acted is exceeding the national boundaries.

Algorithmic citizenship is analyzed as a surveillance policy suggested by the US National Security Agency. (Lippold, J.C. 2016) This type of citizenship is designed to digitally distinguish between the "legal" citizens and the foreigners depending on the algorithms that are produced through data inputs of the communication networks. It is not citizenship that is assigned at birth, rather it is constantly subject of interrogation, quantification, and rewriting. (Bridle, J. 2016) Technology in the algorithmic citizenship can influence the actual existence of the citizens and challenge their identities. Furthermore, it can convert the style of citizen performance of the video games to impact the real-life practices of citizenship. Gaming citizenship is a type of video engagement could transfer civic traditions from fantasy world into reality. (Davisson, A\& Gehm, D. 2014)

From an informatics perspective, the media can play role in the information sharing practices that may emphasize the citizenship performance. Tremblay, M. and Landreville, P. 2015, suggest that sharing information in a top-down direction would reinforce empowerment, whereas bottom-up direction reinforce the procedural justice. Furthermore, there are some evidence that learning soft skills could strengthen the sense of citizenship. (Gutierrez, E.D. et al. 2017) The learning process that involves self-development would improve the social and political engagement and give the people the opportunity to be empowered. It suggests that this type of learning is designed for the active producers not for customers' society.

\section{Citizenship in Egypt:}

In the Egyptian case, many variables play role in influencing the development of citizenship concept portrayed by the media after 2011 revolution. Alexander, A. and Aouragh, M. (2014) concluded that the major dynamics of the Egyptian media content after 2011 was not the affordance of the internet, but in the shifting balance of powers between revolution and counterrevolution. This conclusion would be reinvestigated in this research to evaluate the extent to which the counterrevolution propositions impact the conceptual development of citizenship during this time and whether there are mediated factors that contribute in this development and how. There is an argue that citizenship as a concept operates in tension with radical democratic ideals of equality and liberty for all and citizens are not the residents of a nation-state, but "agents of transformation". (Fletcher, J. 2009) In the early decades of the twenty century, the meaning of the Egyptian citizenship was clear and profound in terms of the relationship between Muslims and Christians. One of the well-known proverbs of "Makhram Obied" (1889-1961) as one of the most famous Christian politicians when describing 
his identity is that "Egypt is not a place we live in, but a place lives in ourselves" and "I am Christian by faith and I am Muslim by nation". (Abo Zied, O. \& Ezzat, H.R. 2003)

The Egyptian citizenship is defined as the sense of belonging that based on active participation and equality among society members. The constitutional moment in the Egyptian history is when people preserve their rights and penetrate ruling power to prove their participation in ruling their country. (Qiladah, W. 2012)

Citizenship during the $25^{\text {th }}$ of Jan 2011 revolution is described as part of the Egyptian society features that were mixture of optimistic and pessimistic attitudes. Creation, ambition, purposefulness, pride, and cooperation are the main optimistic features related to the Egyptian citizenship, however, suspicion, vandalism, collision, conflict, impatience, and intolerance are the pessimistic features. (Elsayed, F. E.M. 2014)

\section{Methodology:}

This study relies on the Pragmatism point of view that is not committed to any one system of philosophy and considers the truth is what works at the time. (Creswell, J. W. 2009). The analysis would apply the mixed methods approach in its concurrent triangulation design (CTD) that combine the data collection of qualitative and quantitative methods with the data analysis of both methods and then compare the data results. (Creswell et al. 2007)

I would answer the research question through analyzing the discourse of the articles published in three of the most popular Egyptian newspapers across seven years from 2011 to 2017 that mentioned the "Citizenship" in the title or in the body of the texts. Alyoum AlSabea published about 85 article, Al Masry Alyoum published 285 articles and Al Watan published 100 article. After filtering the articles to match the area of the research interest by excluding the irrelevant content, the total number of articles under analysis are 253. The principal of citizenship as rights and duties have been classified to subcategories. The civic rights include the freedom of belief, the right of knowledge, the freedom of expression. The social rights include the right of education, the right of work, the right of equality, the right of justice. The political rights include the right of voting, the right of nominating, the freedom of political practices. On the other hand, the citizenship as duties has been classified to duties toward state and duties toward society (Appendix 1). The main arguments extracted from the analysis are sixteen (Appendix 2). Each argument is one of the citizenship facets that the newspapers demonstrated and proved as an appropriate interpretation of the Egyptian citizenship as it should be.

The triangular analysis involves three dimensions, the first is the vertical analysis that describe the development of each argument across years and investigates the potential reasons of this development. The second is the horizontal analysis that demonstrates the dominant arguments that interpret the concept of citizenship from certain point of view in each year. The third dimension merges the findings of the first and second dimensions and investigates the potentiality of any statistical significance in the relationships between the three main citizenship rights and any of the arguments employed in the newspapers discourse to portray citizenship in a certain 
interpretation.

Thus, the third dimension involves testing the validity of three hypotheses as follows:

$\mathrm{H}_{1}$ : There is no correlation between focusing on civil rights and tendency to employ any of the citizenship arguments.

$\mathrm{H}_{2}$ : There is no correlation between focusing on social rights and tendency to employ any of the citizenship arguments.

$\mathrm{H}_{3}$ : There is no correlation between focusing on political rights and tendency to employ any of the citizenship arguments.

\section{Findings:}

This section starts with investigating the validity of the three main hypotheses of the research. The principal claim is that no significant correlation between discussing any of the civic, social, and political rights of citizenship and the utilization of certain arguments. Basically, we can accept this claim regarding the articles of 2012 that show no significant relations between the two variables.

On the other hand, there is a statistical evidence to reject the three hypotheses regarding the articles published in the rest of the years. First, the assumption that there are no correlations between writing about civic rights and using certain argument is accepted regarding the articles that have been published in 2013, 2014, 2015, and 2016. However, it is rejected in 2011 and in 2017.

Second, the assumption that there are no correlations between writing about social rights and using certain argument is completely rejected in all years, except in 2012 as we mentioned earlier. This result may indicate a common and consistent interest in framing the discourse about general social rights of citizenship across time in all articles of the three newspapers. Third, the assumption that there is no significant correlation between writing about the political rights and using certain argument is accepted in 2011, 2013, and 2016, however, it is rejected in 2014, 2015, and 2017. The next vertical analysis is to show how arguments have been employed across years and then demonstrating the attendance of certain arguments in each year.

\section{Development of citizenship arguments (2011-2017)}

Generally, as we can see in Figure1, there has been a high utilization of many arguments in 2011, the year of 25Jan revolution, to demonstrate the real meaning of citizenship from different perspectives followed by a dramatic drop in using arguments in 2012, the year of the first freely presidential elections after revolution, this drop is not justified except for the limited number of total articles talking about citizenship comparing to the other years. In the following two years, 2013, the year of the $30^{\text {th }}$ of June uprising against Muslim Brotherhood government, and 2014, the year of the second presidential elections after revolution and launching war against terrorism, we can observe a gradual straight increasing to employ arguments quantitatively and qualitatively followed by another remarkable drop in 2015. A very clear increase in the number of citizenship arguments is in 2016 which continues until reaching the highest level in 2017. 


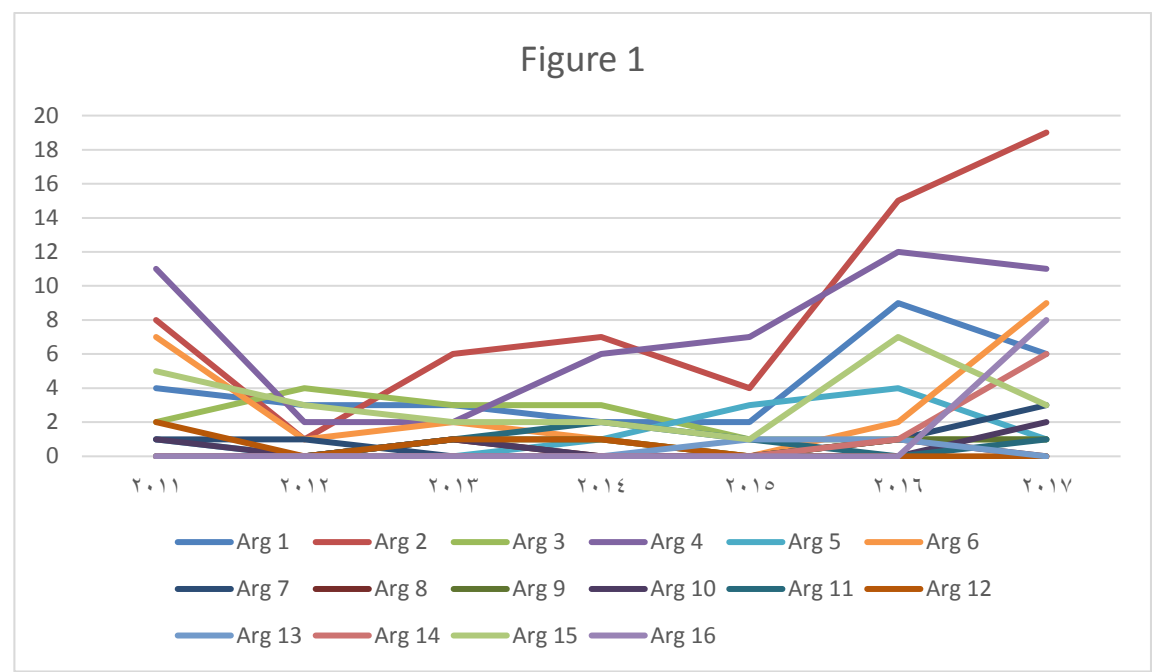

We can talk more specifically about the development of each argument across years if we look at Figure 2, we can categorize the arguments to five classes, the first class arguments are the least in usage and fifth class is the highest. On the first class we find that "Dubai model of citizenship is the best for Egypt", this argument supports the United Arab of Emirates model of citizenship which reduces the importance of democratic institutions and practices and makes the ruling authority is the sole actor in decision-making processes without any popular participation and correlate this policy with achieving higher levels of economic prosperity and well-being for the people. The second argument that underpins the first category is that "Transparency and clarity are essentials for actualizing citizenship".

The second class of arguments involves "Citizenship means fulfilling women rights of equality and justice in the Egyptian society", "War against terrorism is not sufficient to establish citizenship", "Media role is supporting false interpretations of citizenship", "Defeating terrorism is the right start to enjoy citizenship rights", and "Historically, The Egyptian personality attitudes are not supporting the resistance for grabbing citizenship rights". The third class of arguments includes "Absence of citizenship rights can be justified in many ways", "The relationship between Muslim Brotherhood and citizenship is problematic", and "Citizenship is a matter of duties should be fulfilled not just a matter of rights". The forth class consists of the following arguments, "Corruption and dictatorship destroy citizenship possibilities", "Real citizenship culture moderates Muslim and Christian extremism", and "Egyptian Citizenship is above all individuals. The highest and fifth class involves, "Citizenship means fulfilling Christian civic, social, and political rights", and "Citizenship culture is generally absent in the Egyptian society". It is important to explain the reasons that make some arguments appear in certain category, but the reasons are just an attempt to correlate media variables with the broader social and political context that has witnessed many transformations. 


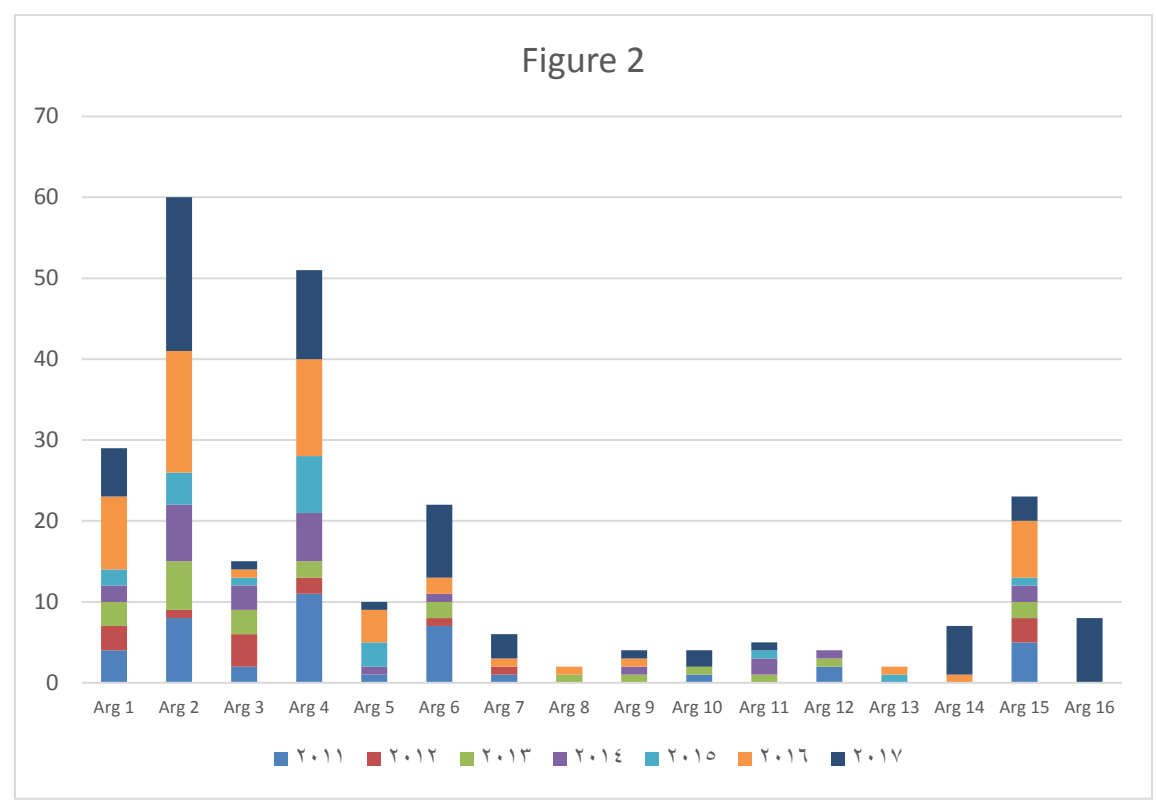

\section{Arguments ${ }^{6}$ attendance across time:}

The years that used a wide variety of arguments were the last two years (2016 -2017), the dominant argument is that citizenship is to give Christians all their civic, social, and political rights, without any mention to the entitlement duties toward the society or the state. (Figure 3) The second dominant argument is that citizenship culture is generally absent from the Egyptian society. In 2012 and 2015 only seven and eight arguments respectively used to present citizenship concept. The remarkable observation is that the relationship between Muslim Brotherhood and citizenship is problematic as an argument is dominant in 2012 and greater than any other year. We can notice a clear attendance to the argument that citizenship culture would moderate Christian and Muslim extremism only in 2011 and 2017. Very limited usage of this argument is in the other years and complete absence in 2015. 


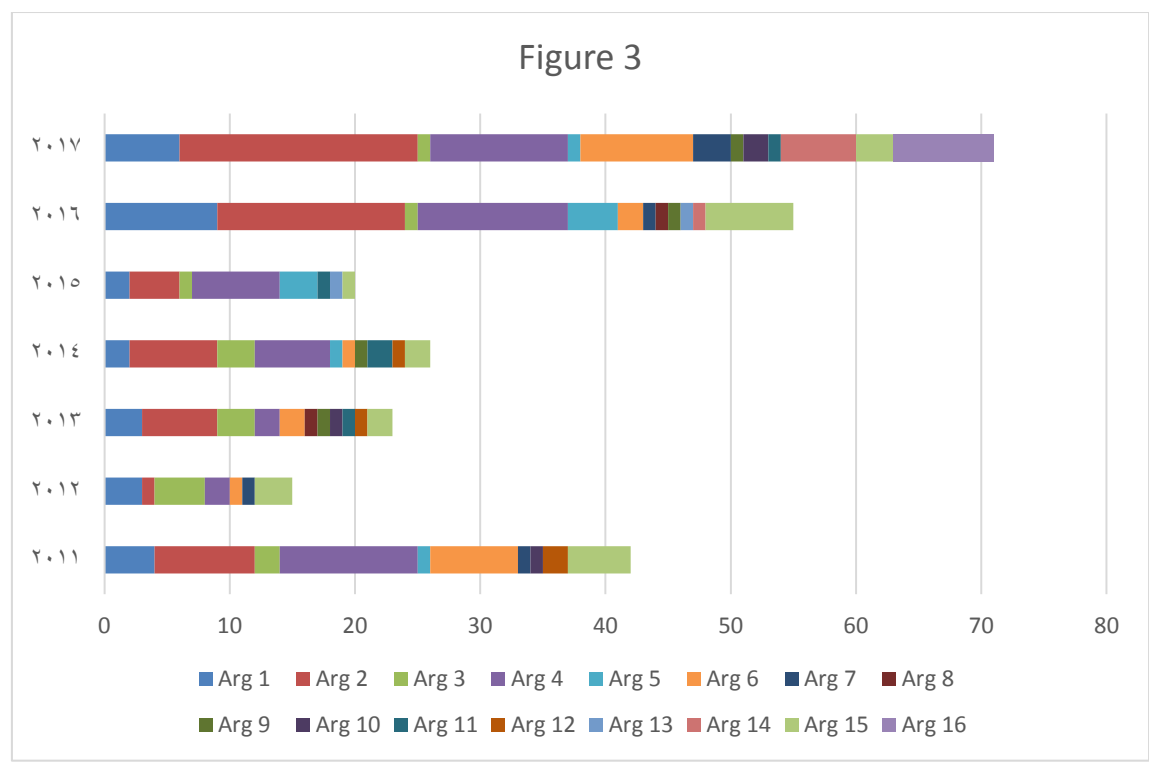

\section{Convergence Analysis:}

In this part, an intersectional investigation is made to explore the potential correlations between main research variables and test the validity of some relationships between the principal arguments and the three dimensions of citizenship rights besides the duties toward the state and toward the society.

First, it is noted that writing about the general citizenship rights is obviously greater than articles that focus only on any certain civic, social, or political right. The articles that interest in rights such as right of knowledge, education, work, voting, etc. are limited comparing to the general perspective of discussing citizenship rights. The only exception to this fact is the frequencies of the right of belief as one of the major civic rights and that was an incentive to know whether there is any significance of the statistical correlations between it and the sixteen used arguments. The analysis revealed statistical significance to the correlation between the right of belief and the absence of citizenship culture from the Egyptian society $\left(\mathrm{Chi}^{2}, 02\right)$ and that real citizenship culture can moderate the Muslim and Christians extremism $\left(\mathrm{Chi}^{2}, 00\right)$.

Discussing citizenship concepts has a significant correlation with arguing that citizenship is a matter of duties should be fulfilled, not just a matter of rights should be grabbed. This claim is repeated concurrently with citizenship duties toward the society and the state in 2017. (Appendix 3) The interesting point in this finding is that the general civic rights are also significantly correlated with arguing that citizenship is to fulfil Christians rights besides the claim that citizenship as a concept can be defined in an exact and exclusive meaning. Al-Azhar as a trustful reference being the oldest religious institution in Egypt and the Islamic world declared that good citizenship means to accept the other without any specification about what exactly 
should be accepted. A member of Procter \& Gamble's company board of directors in Egypt confirmed that the good citizenship is an essential condition for working within the company. Moreover, he stated a definition of good citizenship that is consists of four values that underpin the company and the employer interests. The definition involves social efficacy, diversity and replacement, gender equality, and environmental sustainability. ( ${ }^{\top}$ ) In a different context, Alexandria Pop and patriarch of St. Mark stated in an interview with foreign media that the Egyptian Church contributed in taking away Mohamed Morsi -the first freely elected president after $25^{\text {th }}$ of Jan revolution- as an act of actualizing citizenship and has no relation with politics. $(\vee)$ The endowments ministry shared a unified Friday prayer's speech all over the country's mosques to deliver that citizenship is to welcome tourists and visitors of Egypt. (^)

Claiming that the absence of citizenship rights can be justified in many ways has significant correlation with discussing citizenship as duties toward society in 2011, 2013, and 2014. In 2011, the achievements of the national football team were enough to be proud of your Egyptian nationality rather than asking for citizenship entitlements. However, in 2013 and 2014 the reasons to forget about civic, social, and political rights of citizenship was different. The war against terrorism is the first and ultimate priority, any other demands of any kind not just citizenship rights are disabling of counterterrorism efforts and may be accused of supporting terrorists or at least of being a reason for postponing defeat of terrorism. ( 9 )

On the other hand, the general civic rights are significantly correlated with arguing that citizenship culture is generally absent in the Egyptian society and with the claim that corruption and dictatorship are destroying citizenship possibilities.

\section{Conclusions:}

"Citizenship" as a floating concept:

The development of citizenship concept in this study can be characterized by laxity and lack of specificity. It shows a remarkable ability to be reshaped and convey multiple meanings across seven years (2011-2017).

Proposing citizenship as political rights is influenced by the tense relationship between Muslim Brotherhood and ruling authorities and other opposition movements, which led to marginalizing the attention to general political rights and duties for all society members and focusing only on distorting and accusing them of intellectual contradiction with the concept of citizenship.

Discussing the duties dimension of citizenship concept seems to relate to a justification discourse that provides reasons for the absence of citizenship rights. The tendency to use this discourse varies depending on the changing of the political and social conditions.

Limitations:

Some of the limitations that encounter this research are that only three popular newspapers were analysed and they represent a limited area of the Egyptian media space. The so-called official governmental newspapers such as Al-Ahram and Akhbar- Al-Yom are not involved besides other partisan newspapers. The excluded 
newspapers might have claimed different arguments from those which have been defined. Secondly, the online archiving of articles about citizenship maybe insufficient to provide all possible arguments that underpin discussion of citizenship rights and duties. Thirdly, the statistical analysis focuses on significant correlations between the general citizenship variables and the suggested arguments. Nevertheless, investigating the correlations between specified civic, social, and political rights might have produced more extended findings.

\section{References:}

Abo Zied, O. E., Ezzat, H.R. 2003. Egyptian citizenship and the future of democracy, New visions for a changing world. Proceedings of the 17th Annual conference of political research, First Part, 28.

Al- Assasy, A. Z. 2011. Abstracts of the International institution of Islamic Thought. Epistemological Studies Centre, First Part.

Alexander, A. \& Aouragh, M. 2014. Egypt's Unfinished Revolution: The Role of the Media Revisited. International Journal of Communication (19328036), 8, 890-915.

Balibar, É. 2010. Antinomies of citizenship. Journal of Romance Studies, 10, 1-20. Bridle, J. 2016. Algorithmic Citizenship, Digital Statelessness. GeoHumanities, 2, 377-381.

Bunce, S. 2015. Citizenship: The Legality of Breaking the Law. Language in India, 15, 243-246.

Cheney-Lippold, J. 2016. Jus Algoritmi: How the National Security Agency Remade Citizenship. International Journal of Communication (19328036), 10, 1721-1742.

Chi, M. T. 2009. Three types of conceptual change: Belief revision, mental model transformation, and categorical shift. International handbook of research on conceptual change. Routledge.

Chouliaraki, L. 2010. Self-mediation: new media and citizenship. Critical Discourse Studies, 7, 227-232.

Coleman, S. \& Blumler, J. G. 2009. The Internet and democratic citizenship: Theory, practice and policy, Cambridge University Press.

Creswell, J. W. \& Clark, V. L. P. 2007. Designing and conducting mixed methods research.

Creswell, J. W. 2011. Research Design, qualitative and quantitative, and mixed methods approaches. Sage publications.

Dahlgren, P. 2009. Media and Political Engagement. Cambridge University Press, First Published.

Danisch, R. 2011. Jane Addams, Pragmatism, and Rhetorical Citizenship in Multicultural Democracies. At the Interface / Probing the Boundaries, 74, 37-58.

Davission, A. \& Gehm, D. 2014. Gaming Citizenship: Video Games as Lessons in Civic Life. Journal of Contemporary Rhetoric, 4, 39-57.

Del Carment Garcia Galera, M., Munoz, C. F. \& Pedrosa, L. P. 2017. Youth empowerment through social networks. Creating participative digital citizenship. Communication \& Society, 30, 129-140.

Deligiaouri, A. 2017. Self mediation. New media, citizenship and Civil Selves. 
Journal of Language \& Politics, 16, 141-144.

Diez-Gutierrez, E. \& Diaz-Nafria, J.-M. 2018. Ubiquitous learning ecologies for a critical cyber-citizenship. Ecologías de aprendizaje ubicuo para la ciberciudadanía crítica., 26, 49-58.

El-Nawawy, M. \& Elmasry, M. H. 2016. The Signs of a Strongman: A Semiotic and Discourse Analysis of Abdelfattah Al-Sisi's Egyptian Presidential Campaign. International Journal of Communication (19328036), 10, 2275-2296.

Elsayed, F. E. 2014. Features of the Egyptian society in Video Clips of NYT and AlWatan online Newspapers - Semiotic Study. International Journal of Communication and Social Research, 2.

Fletcher, J. 2009. Of Minutemen and Rebel Clown Armies: Reconsidering Transformative Citizenship. Text \& Performance Quarterly, 29, 222-238.

Gordon, J. 2007. EGYPT: Liberalism without democracy: Nationhood and citizenship in Egypt, 1922-1936. The Middle East Journal, 61, 532-533.

Grabe, M. E. \& Myrick, J. G. 2016. Informed Citizenship in a Media-Centric Way of Life. Wiley-Blackwell.

Hamdy, N. \& Gomaa, E. H. 2012. Framing the Egyptian Uprising in Arabic Language Newspapers and Social Media. Journal of Communication, 62, 195-211.

Hatem, M. F. 1994. Egyptian discourses on gender and political liberalization: Do secularist and islamist views really differ? Middle East Journal, 48, 661.

Hinck, A. 2016. Ethical Frameworks and Ethical Modalities: Theorizing Communication and Citizenship in a Fluid World. Communication Theory (10503293), 26, 1-20.

Hintz, A., Dencik, L. \& Wahl-Jorgensen, K. 2017. Digital Citizenship and Surveillance Society. International Journal of Communication (19328036), 11, 731739.

Ivic, S. 2011. The Postmodern Liberal Concept of Citizenship. At the Interface / Probing the Boundaries, 74, 3-18.

John, J. S. 2008. Assessing Citizenship: Foundation, Identity, Place, and Obsolescence. Review of Communication, 8, 409-419.

Kim, D. H. \& Kwak, N. 2017. Media Diversity Policies for the Public: Empirical Evidence Examining Exposure Diversity and Democratic Citizenship. Journal of Broadcasting \& Electronic Media, 61, 682-702.

Kitsch, S. R. 2017. Contemporary Rhetorical Citizenship. Rhetoric \& Public Affairs, 20,363-366.

Lane, P. 2009. Mediating national language management: the discourse of citizenship categorization in Norwegian media. Language Policy, 8, 209-225.

Leydet, D., Edward N. Zalta (ED.) 2017. Citizenship. The Stanford Encyclopedia of Philosophy, (Fall Edition).

Lim, M. 2012. Clicks, Cabs, and Coffee Houses: Social Media and Oppositional Movements in Egypt, 2004-2011. Journal of Communication, 62, 231-248.

Livio, O. 2017. Citizenship as a Communicative Construct. International Journal of Communication (19328036), 11, 2605-2623.

Macdonald, M. N., Hunter, D. \& O'regan, J. P. 2013. Citizenship, community, 
and counter-terrorism: UK security discourse, 2001-2011. Journal of Language \& Politics, 12, 445-473.

Maghraby, S. E. \& Abu El Ela, Y. 2014. Framing Political Change in Egypt: How Ideology Influences Coverage. Global Media Journal: African Edition, 8, 231-274.

Mitchell, K. S., ARSHAM KUFTINEC, S. \& BROD, H. 2009. How Does Citizenship Mean? Text \& Performance Quarterly, 29, 201-204.

Mohamed, A. S. 2012. On the Road to Democracy: Egyptian Bloggers and the Internet 2010. Journal of Arab \& Muslim Media Research, 4, 253-272.

Nersessian, N. J. (1992). How do scientists think? Capturing the dynamics of conceptual change in science. In R. Giere (Ed.), Minnesota Studies in the Philosophy of Science (pp. 3-45). Minneapolis: University of Minnesota Press

Neubauer, R. 2011. Neoliberalism in the Information Age, or Vice Versa? Global Citizenship, Technology, and Hegemonic Ideology. Triple C (Cognition, Communication, Co-Operation): Open Access Journal for a Global Sustainable Information Society, 9, 195-300.

Omwoha, J. 2017. Formation of citizenship through radio talk participation in Kenya. Journal of African Media Studies, 9, 181-194.

Rinke, E. M. \& Röder, M. 2011. Media Ecologies, Communication Culture, and Temporal-Spatial Unfolding: Three Components in a Communication Model of the Egyptian Regime Change. International Journal of Communication (19328036), 5, 1273-1285.

Robinson Chavez, R. 2017. On Militarized Borders and Militarized Citizenship. Women's Studies in Communication, 40, 334-338.

Robinson Chávez, R. 2017. On Militarized Borders and Militarized Citizenship. Women's Studies in Communication 40(4): 334-338.

Rufo, K. \& Atchison, R. J. 2011. From Circus to Fasces: The Disciplinary Politics of Citizen and Citizenship. Review of Communication, 11, 193-215.

Tracy, K. \& Hughes, J. M. F. 2014. Democracy-Appealing Partisanship: A Situated Ideal of Citizenship. Journal of Applied Communication Research, 42, 307-324.

Tremblay, M. \& Landreville, P.-E. 2015. Information Sharing and Citizenship Behaviours: Mediating the Roles of Empowerment, Procedural Justice, and Perceived Organizational Support. International Journal of Business Communication, 52, 347 368.

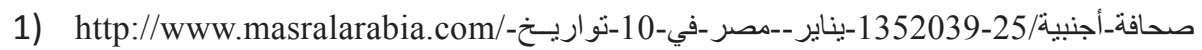
بعد-الثورة

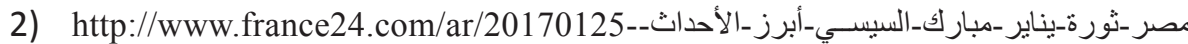
الإخو ان-المسلمون

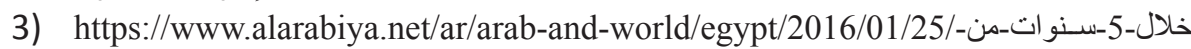
html. ثورة-يناير -ماذا-جرى-في_مصر؟

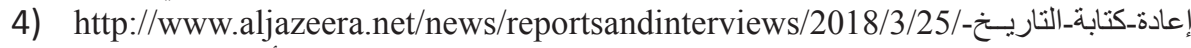
المصري-وحذف_أرشيف_ثورة-بيناير

5) http://citizen-ex.com/citizenship

6) https://www.elwatannews.com/news/details/2080543 
7) https://www.elwatannews.com/news/details/2327897

8) https://dbonfrdgauzmg.cloudfront.net/news/details/1162937

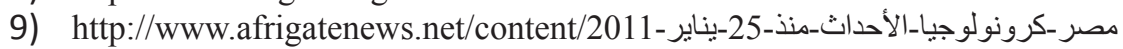

\section{Appendix: 1}

\section{Citizenship Arguments Order}

\begin{tabular}{|c|c|}
\hline 1 & Egyptian Citizenship is above all individuals. \\
\hline 2 & $\begin{array}{r}\text { Citizenship means fulfilling Christian civic, social, and political } \\
\text { rights }\end{array}$ \\
\hline 3 & $\begin{array}{r}\text { The relationship between Muslim Brotherhood and citizenship is } \\
\text { problematic }\end{array}$ \\
\hline 4 & Citizenship culture is generally absent in the Egyptian society. \\
\hline 5 & Absence of citizenship rights can be justified in many ways. \\
\hline 6 & Real citizenship culture moderates Muslim and Christian extremism. \\
\hline 7 & $\begin{array}{r}\text { Citizenship means fulfilling women rights of equality and justice in } \\
\text { the Egyptian society. }\end{array}$ \\
\hline 8 & Transparency and clarity are essentials for actualizing citizenship. \\
\hline 9 & War against terrorism is not sufficient to establish citizenship. \\
\hline 10 & Media role is supporting false interpretations of citizenship. \\
\hline 11 & Defeating terrorism is the right start to enjoy citizenship rights. \\
\hline 12 & $\begin{array}{l}\text { Historically, The Egyptian personality attitudes are not supporting } \\
\text { the resistance for grabbing citizenship rights. }\end{array}$ \\
\hline 13 & Dubai model of citizenship is the best for Egypt. \\
\hline 14 & "Good Citizenship" has a direct description can be illustrated. \\
\hline 15 & Corruption and dictatorship destroy citizenship possibilities. \\
\hline 16 & $\begin{array}{r}\text { Citizenship is a matter of duties should be fulfilled not just a matter } \\
\text { of rights. }\end{array}$ \\
\hline
\end{tabular}


Appendix: 2

Relationships Statistical Significance

\begin{tabular}{|c|c|}
\hline Year & Relationships \\
\hline \multirow{5}{*}{2017} & $\begin{array}{r}\text { General civic rights*Citizenship means fulfilling Christian civic, } \\
\text { social, and political rights * "Good Citizenship" has a direct } \\
\left.\text { description can be illustrated. ( } \mathrm{Chi}^{2}, 03\right)\end{array}$ \\
\hline & $\begin{array}{l}\text { General Social rights *Citizenship means fulfilling Christian } \\
\text { civic, social, and political rights *Corruption and dictatorship } \\
\text { destroy citizenship possibilities. }\left(\mathrm{Chi}^{2}, 00\right)\end{array}$ \\
\hline & $\begin{array}{r}\text { General Political rights*Citizenship means fulfilling Christian } \\
\text { civic, social, and political rights * "Good Citizenship" has a direct } \\
\text { description can be illustrated. }\left(\mathrm{Chi}^{2}, 03\right)\end{array}$ \\
\hline & $\begin{array}{r}\text { Duties toward State*Citizenship is a matter of duties should be } \\
\text { fulfilled not just a matter of rights }\left(\mathrm{Chi}^{2}, 00\right)\end{array}$ \\
\hline & $\begin{array}{r}\text { Duties toward Society*Citizenship is a matter of duties should be } \\
\text { fulfilled not just a matter of rights }\left(\mathrm{Chi}^{2}, 00\right)\end{array}$ \\
\hline 2016 & $\begin{array}{r}\text { General Social rights*Citizenship means fulfilling Christian } \\
\text { civic, social, and political rights }\left(\mathrm{Chi}^{2}, 03\right) * \text { Absence of citizenship } \\
\text { rights can be justified in many ways }\left(\mathrm{Chi}^{2}, 00\right)\end{array}$ \\
\hline \multirow[t]{2}{*}{2015} & $\begin{array}{r}\text { General Political rights*The relationship between Muslim } \\
\text { Brotherhood and citizenship is problematic }\left(\mathrm{Chi}^{2}, 01\right) * \text { Egyptian } \\
\text { Citizenship is above all individuals }\left(\mathrm{Chi}^{2}, 05\right)\end{array}$ \\
\hline & $\begin{array}{r}\text { General Social rights*Absence of citizenship rights can be } \\
\text { justified in many ways. }\left(\mathrm{Chi}^{2}, 05\right)\end{array}$ \\
\hline \multirow{3}{*}{2014} & $\begin{array}{r}\text { General Political rights*The relationship between Muslim } \\
\text { Brotherhood and citizenship is problematic }\left(\mathrm{Chi}^{2}, 01\right) * \text { Egyptian } \\
\text { Citizenship is above all individuals }\left(\mathrm{Chi}^{2}, 05\right)\end{array}$ \\
\hline & $\begin{array}{r}\text { General Social rights*Egyptian Citizenship is above all } \\
\text { individuals }\left(\mathrm{Chi}^{2}, 05\right) * \text { Defeating terrorism is the right start to } \\
\text { enjoy citizenship rights }\left(\mathrm{Chi}^{2}, 03\right)\end{array}$ \\
\hline & $\begin{array}{r}\text { Duties toward Society*Absence of citizenship rights can be } \\
\text { justified in many ways. }\left(\mathrm{Chi}^{2}, 02\right)\end{array}$ \\
\hline \multirow{2}{*}{2013} & $\begin{array}{r}\text { General Social rights* Corruption and dictatorship destroy } \\
\text { citizenship possibilities }\left(\mathrm{Chi}^{2}, 04\right)\end{array}$ \\
\hline & $\begin{array}{r}\text { Duties toward Society*Absence of citizenship rights can be } \\
\text { justified in many ways. }\left(\mathrm{Chi}^{2}, 02\right)\end{array}$ \\
\hline 2012 & No relationships with statistical significance. \\
\hline
\end{tabular}




\begin{tabular}{|l|r|}
\hline \multirow{2}{*}{2011} & $\begin{array}{r}\text { General civic rights*Citizenship culture is generally absent in the } \\
\text { Egyptian society }\left(\mathrm{Chi}^{2}, 00\right) * \text { Corruption and dictatorship destroy } \\
\text { citizenship possibilities }\left(\mathrm{Chi}^{2}, 04\right)\end{array}$ \\
\cline { 2 - 3 } & $\begin{array}{r}\text { General Social rights*Citizenship culture is generally absent in } \\
\text { the Egyptian society }\left(\mathrm{Chi}^{2}, 00\right)\end{array}$ \\
\cline { 2 - 3 } & $\begin{array}{r}\text { Duties toward Society*Absence of citizenship rights can be } \\
\text { justified in many ways. }\left(\mathrm{Chi}^{2}, 02\right)\end{array}$ \\
\hline
\end{tabular}

Appendix: 3

Analytical Sheet

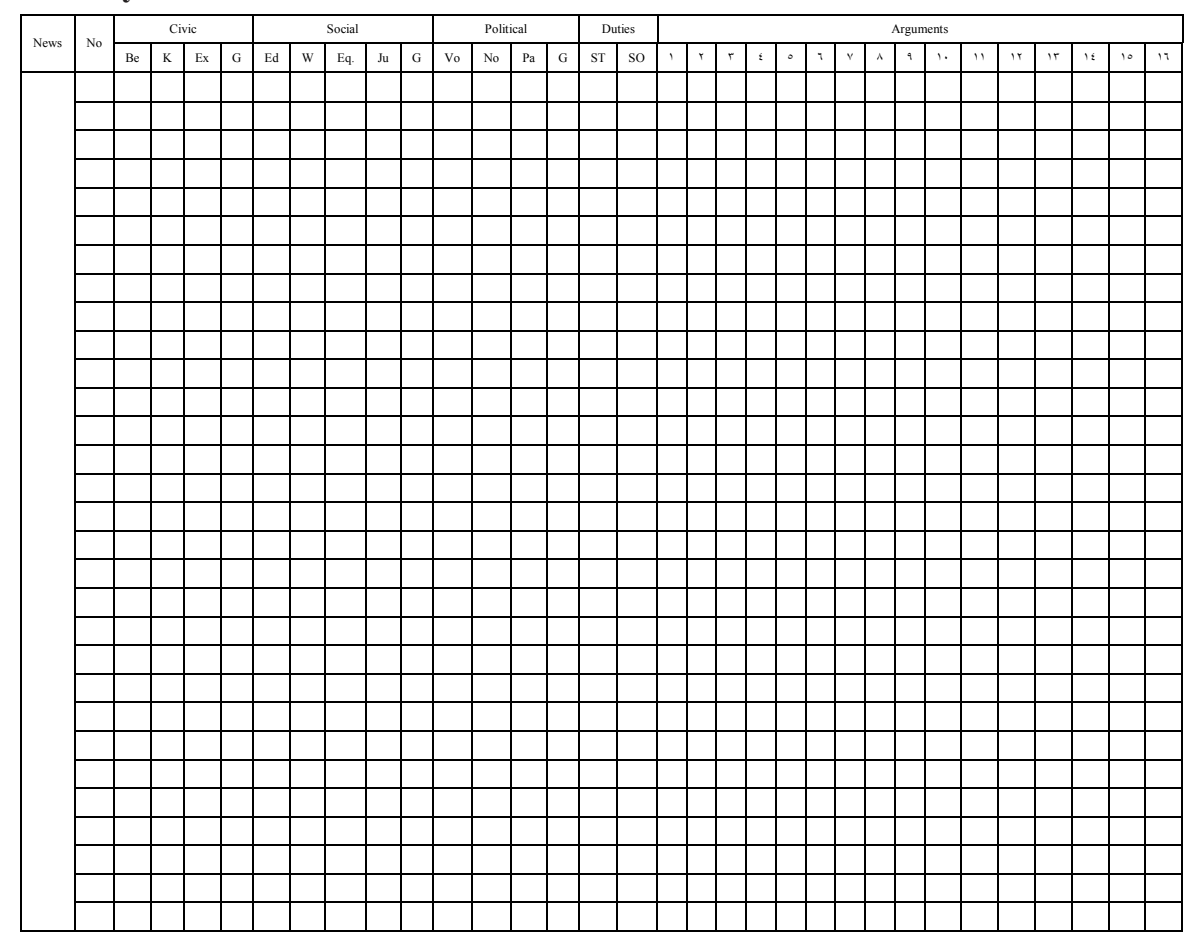

